\title{
Bazı Buğdaygil Bitki Türlerinin Yem Kalite Değerlerinin Belirlenmesi ve Biplot Analiz Yöntemi ile Özelliklerarası ilișkilerin Değerlendirilmesi
}

\author{
Mehmet BAȘBAĞ ${ }^{1}$, Erdal ÇAÇAN², *Mehmet Salih SAYAR ${ }^{3}$ \\ 1Dicle Üniversitesi Ziraat Fakültesi Tarla Bitkileri Bölümü, Diyarbakır, Türkiye \\ ${ }^{2}$ Bingöl Üniversitesi, Genç Meslek Yüksekokulu, Bitkisel ve Hayvansal Üretim Bölümü, \\ Genç-Bingöl, Türkiye \\ ${ }^{3}$ Dicle Üniversitesi Bismil Meslek Yüksekokulu Bitkisel ve Hayvansal Üretim Bölümü, \\ Bismil-Diyarbakır, Türkiye \\ ${ }^{*}$ Corresponding author e-mail (Sorumlu yazar e-posta): msalihsayar@hotmail.com
}

\begin{abstract}
Öz
Hayvan beslemesinde kullanılacak kaba yemlere ait besin içeriklerinin ve kalite parametrelerinin önceden bilinmesi bașarılı bir hayvancılık için büyük öneme sahiptir. Bu çalıșma doğal olarak yetișen bazı buğdaygil yem bitkisi türlerinin yem kalitesini belirlemek amacıyla yürütülmüștür. Dicle Üniversitesi kampüs alanında yeralan doğal vejetasyondan 2017 yılında toplanan 13 değișik buğdaygil cinsine ait 15 buğdaygil yem bitkisi türü, araștırmanın materyalini olușturmuștur. Bitki türlerine ait doğadan toplanan tohumlar Dicle Üniversitesi Ziraat Fakültesi Araștırma arazinde ayrı ayrı parsellere ekilerek, çiçeklenme döneminde ot ile ilgi analizlerinin yapılması için hasat edilmiștir. Her parselden 3 tekerrürlü olarak alınan kuru ot örnekleri Dicle Üniversitesi Bilim ve Teknoloji Uygulama ve Araștırma Merkezi (DÜBTAM) Laboratuarlarında analiz edilmiștir. İncelenen özelliklere ait veriler üzerinde yapılan istatiksel analiz sonucuna göre, incelenen tüm özellikler için buğdaygil bitki türlerinin 0.01 düzeyinde birbirlerinden farklı olduğu saptanmıștır. Ayrıca araștırmada incelenen özelliklerin 15 buğdaygil türü arasında așağıdaki aralıklarda değișim gösterdiği belirlenmiștir; ham protein oranı (HP) - \%6.2-19.3; kuru madde oranı (KMO) - \%88.9-91.7; asit deterjanda çözünmeyen lif oranı (ADF) - \%22.9-43.2; nötral deterjanda çözünmeyen lif oranı (NDF) - \%45.9-74.6; asit deterjanda çözünmeyen protein oranı (ADP) - \%0.08- 0.63; sindirilebilir kuru madde oranı (SKM) \%55.3-71.0; kuru madde tüketimi oranı (KMT) - \%1.61-2.62 ve nisbi yem değerleri (NYD) - 68.9-143.1. Biplot analiz yöntemiyle yapılan analizlerde ise așağıdaki sonuçlara ulașılmıștır. İncelenen özelliklerin birbirinden farklı 5 grup olușturduğu belirlenmiștir. Kuru madde oranı, ADF ve NDF oranlarından olușan 3 özellik arasında olumlu ve önemli ilișki saptanmıș olup, bu üç özellik bakımından sindirilebilirlik oranı ve nisbi yem değerleri en düșük olan Bromus tectorum türü öne çıkmıștır. Öte yandan, aynı grupta yeralan ham protein oranı, magnezyum içeriği ve sindirilebilir kuru madde oranı özellikleri arasında da olumlu ve önemli ilișki olduğu saptanmıștır. Bu üç özelliğin bulunduğu grupta yer alan tek buğdaygil türü olan Lolium perenne türü dikkat çekici bulunmuștur. Yine aynı șekilde nisbi yem değeri ve kuru madde tüketim oranı özellikleri arasında da önemli olumlu ilișki olduğu belirlenmiș olup, iki özellik bakımından ise Festuca arundinacea ve Phalaris canariensis türleri öne çıkmıștır.
\end{abstract}

Anahtar Kelimeler: ADF, biplot analiz yöntemi, buğdaygil türleri, ham protein, NDF

\section{Determining Feed Quality Values of Some Grass Species and Assessments on Relations Among the Traits with Biplot Analysis Method}

\section{Abstract}

Knowing in advance nutritional contents and quality parameters of roughage used in livestock feeding is of great importance for a successful animal husbandry. This study was carried out to determine the feed quality of some grass species collected from natural vegetation of Dicle University campus in 2017. The material of the study consisted of 15 grass species, belonging to 13 genus of Poaceae family. The seed of the plant species were sown in plots separately in Research Area of Agriculture Faculty of Dicle University, Diyarbakır, in November 2017. The species were harvested for the forage analysis at the blooming period of the species. The samples of dry matter of the grass species taken from each plot with 3 replications were analyzed in Dicle University Science and Technology Application and Research Center (DUBTAM) Laboratories. The statistical analysis indicated that there were highly significant differences $(P<0.01)$ among 
the grass species in terms all of the investigated traits. Additionally, the following ranges were determined among the 15 Grass species in the investigated traits; crude protein contents (CP) - 6.2-19.3\%; dry matter contents (DMC) - 88.9-91.7\%; acid detergent fiber (ADF) - 22.9-43.2\%; neutral detergent fiber (NDF) 45.9-74.6\%; insoluble protein content in acid detergent (ADP) - 0.08- 0.63\%; digestible dry matter content (DDM) - 55.3-71.0\%; dry matter intake (DMI) - 1.61-2.62\% and relative feed value (RFV) - 68.9-143.1. Mainly the following results revealed with biplot analysis. The investigated traits formed 5 separate groups. ADF and NDF contents traits took part in the same group. A positive interaction were determined among the dry matter, ADF and NDF features. Bromus tectorum was shown superiorty which has a low digestibility and dry matter content. It was remarkable that only Lolium perenne species came to fore for these traits. Finally; it was determined that there was a significant positive relationship between dry matter intake and relative feed value traits and Festuca arundinacea ve Phalaris canariensis species were found superior for the traits.

Keywords: ADF, biplot analysis method, grass species, crude protein, NDF

"Giriș Ike hayvancılığımızın intiyaç duyduğu kaliteli kaba yemin tedarik edilmesinde yem bitkileri büyük öneme sahiptir (Sayar ve ark., 2010). Yem bitkileri ise botanik açıdan üç gruba ayrılmaktır. Bunlar; buğdaygiller (Poaceae), baklagiller (Fabaceae) ve diğer familyalara ait yem bitkileridir. Yem bitkilerinin büyük çoğunluğu buğdaygil ve baklagil familyaları içerisinde yer almaktadır (Açıkgöz, 2001). Bitkiler alemi içerisinde tek çenekliler (Monocotyledoneae) alt sınıfına giren buğdaygiller familyası (Poaceae), Dünya üzerinde yaklașık 650-785 arasında değișen cins ve 10.000 kadar türden olușmaktadır (Açıkgöz, 2001, Avcıoğlu ve ark., 2009). Yeryüzünde kültürü yapılmakta olan bitkilerin büyük bir bölümü bu familyanın mensubudur. Bunların \%75'ini tahıllar ve yem bitkileri olușturmaktadır (Avcıoğlu ve ark., 2009).

Buğdaygil yem bitkileri karbonhidratça zengin kaba yem üretmektedirler (Sağlamtimur ve ark., 1986). Kültür hayvanlarının beslenmesinde ideal olarak kabul edilen protein ve karbonhidrat oranlarını ancak baklagiller familyasının verdiği proteinli yemler yanında, buğdaygiller familyası yem bitkilerinin verdiği karbonhidratı yemler tamamlamaktadır. Belli bașlı buğdaygil yem bitkileri; Lolium perenne, Dactylis glomerata, Bromus inermis, Poa pratensis, Agropyron cristatum ve Cynodon dactylon türleridir (Kevseroğlu, 2000). Bu türler dıșında çayır mera ve diğer doğal vejetasyonlarda çok sayıda yem bitkisi türüne rastlamak mümkündür. Yonca gibi bazı baklagil yem bitkisitürlerine ait otlar hayvanlarayaș olarak yedirildiğinde, hayvanlara șișmeden kaynaklı büyük problemlere neden olabilmektedir. Bu tür bitkilerin problem teșkil etmeden, otlatma alanlarında kullanılabilmelerinin çözümü olarak, buğdaygil türleri ile karıșı olarak ekilmeleri gösterilmektedir. Ayrıca baklagiller tarafından simbiyotik yolla toprağa kazandırılan azotu en iyi șekilde değerlendiren yine buğdaygil türleridir (Sayar ve Kendal, 2014).

Çayır mera alanlarında yetișen bitkilerin çoğu henüz kültüre alınmamıș doğal olarak yetișen yem bitkileridir. Özellikle buğdaygil yem bitkileri içerisinde kültüre alınan bitki sayısı oldukça azdır. Dolaysıyla bu bitkilerin yem kaliteleri ile ilgili bilgiler de sınırlı düzeydedir. Bu çalıșma, Diyarbakır'ın doğal vejetasyonunda yetișen bazı buğdaygil yem bitkilerinin kalite değerlerini belirlemek ve yem potansiyelinin ortaya çıkarıması amacıyla yürütülmüștür. Ayrıca araștırmada incelenen özelliklerin birbirleriyle ve genotiplerle ilișkisi ise biplot analiziyle belirlenmiș ve grafik halinde sunulmuștur.

\section{Materyal ve Yöntem}

\section{Materyal}

Araștırmanın materyalini buğdaygiller familyasına ait 13 cinsten, toplam 15 bitki türü olușturmaktadır. Araștırma materyalini olușturan buğdaygil bitki türlerine ait tohumlar, 2017 yılının Haziran ayı içerisinde Dicle Üniversitesi kampüs alanı içerisindeki korunaklı doğal vejetasyondan toplanmıștır. Toplanılan materyalden Çizelge 1'de belirtilen buğdaygil türlerine ait tohumlar 2017 yııının Kasım ayında Dicle Üniversitesi Ziraat Fakültesi Araștırma ve Uygulama Arazisinde ekilmiștir. 
Çizelge 1. Araștırmada yer alan buğdaygil yem bitkisi türlerinin Latince, Türkçe ve İngilizce adları Table 1. Latin, Turkish and English names of the studied grass species

\begin{tabular}{llll}
\hline No & Latince Adı & Türkçe Adı & İngilizce Adı \\
\hline 1 & Taeniatherum çaput-medusa (L.) Nevski & Kılçıklı Otlak Arpası & Medusa Head \\
2 & Triticum aestivum L. & Ekmeklik Buğday & Common Wheat \\
3 & Hordeum spontaneum (K. Koch) Thell. & Yabani Arpa & Wild Barley \\
4 & Secale cereale L. & Çavdar & Rye \\
5 & Triticum durum Desf. & Makarnalık Buğday & Durum Wheat \\
6 & Phalaris canariensis L. & Kuș Yemi & Canary Grass \\
7 & Polypogon monspeliensis (L.) Desf. & Tavșan Kuyruğu & Annual Rabbitsfoot Grass \\
8 & Bromus tectorum L. & Kır Bromu & Drooping Brome \\
9 & Avena fatua L. & Yabani Yulaf & Common Wild Oat \\
10 & Alopecurus myosuroides Huds. & Tilki Kuyruğu & Black-Grass \\
11 & Aegilops geniculata Roth. & Yabani Buğday & Ovate Goatgrass \\
12 & Aegilops cylindrica Host. & Yabani Buğday & Jointed Goatgrass \\
13 & Poa pratensis L. & Çayır salkım otu & Kentucky Bluegrass \\
14 & Festuca arundinaceae Schreb. & Kamıșsı Yumak & Tall Fescue \\
15 & Lolium perenne L. & İngiliz Çimi & Perennial Ryegrass \\
\hline
\end{tabular}

Araștırma materyalinin yetiștirildiği Diyarbakır ilinin yetiștirme dönemine (20172018) ve uzun yıllar ortalamasına ait, aylık ortalama sıcaklık ve nisbi nem değerleriyle, aylık toplam yağıș miktarları Çizelge 2'de verilmiștir (Anonim, 2018). Çizelge 2 incelendiğinde araștırmanın yürütüldüğü 2017-2018 ekim dönemine ait aylık ortalama sıcaklık değerlerinin Eylül ayı dıșındaki diğer tüm aylarda, uzun yıllar aylık ortalama sıcaklık değerlerinden daha yüksek olduğu görülmektedir. Ayrıca araștırma yerine 2017-2018 ekim sezonunda düșen toplam yağıș miktarı $(462.7 \mathrm{~mm}$ ) uzun yıllar ortalaması düșen toplam yağıș (483.5) miktarından daha düșük olmuștur. Ancak yetiștirme yılının Mayıs ayında düșen yağıș miktarı (157.8 mm) uzun yıllar ortalamasının (42.8 mm) çok üzerinde olması dikkat çekici bulunmuștur. Mayıs ayında kaydedilen nisbi nem oranı da (\%67.3) yağıș miktarına bağı

Çizelge 2. Diyarbakır ilinin 2017-2018 ekim sezonu ile uzun yıllar ortalamasına ait aylık iklim verileri Table 2. Monthly climate data of Diyarbakır province for 2017-2018 growing season and long years average

\begin{tabular}{lcccccc}
\hline \multirow{2}{*}{ Aylar } & \multicolumn{2}{c}{ Yağıs Miktarı $(\mathrm{mm})$} & \multicolumn{2}{c}{ Ortalama Sıcaklık $\left({ }^{\circ} \mathrm{C}\right)$} & \multicolumn{2}{c}{ Nisbi Nem $(\%)$} \\
\cline { 2 - 7 } & $2017-2018$ & Uzun Yıllar & $2017-2018$ & Uzun Yıllar & $2017-2018$ & Uzun Yıllar \\
\hline Eylül & 0 & 3.9 & 16.6 & 24.9 & 22.3 & 31.2 \\
Ekim & 22.2 & 31.7 & 17.2 & 17.3 & 39.2 & 48.4 \\
Kasım & 21.2 & 53.8 & 10.0 & 9.5 & 67.5 & 68.0 \\
Aralık & 12.8 & 70.1 & 5.8 & 3.9 & 74.1 & 77.5 \\
Ocak & 86.6 & 70.1 & 5.2 & 1.6 & 76.9 & 77.2 \\
Șubat & 86.4 & 67.8 & 7.6 & 3.6 & 74.5 & 73.3 \\
Mart & 11.6 & 65.7 & 12.4 & 8.3 & 62.8 & 66.5 \\
Nisan & 48.8 & 68.5 & 15.9 & 13.8 & 52.9 & 63.4 \\
Mayıs & 157.8 & 42.8 & 19.4 & 19.2 & 67.3 & 56.8 \\
Haziran & 14.4 & 8.0 & 26.6 & 26.2 & 37.4 & 36.6 \\
Temmuz & 0 & 0.7 & 31.2 & 31.1 & 24.1 & 26.0 \\
Ağustos & 0 & 0.4 & 31.5 & 30.4 & 24.3 & 25.0 \\
\hline Top./Ort. & 462.7 & 483.5 & 17.8 & 15.8 & 51.9 & 54.2 \\
\hline
\end{tabular}


Çizelge 3. Araștırma alanına ait toprak analiz sonuçları

Table 3. Soil analysis results of the research area

\begin{tabular}{lcccccc}
\hline Bünye & $\begin{array}{c}\text { Tuzluluk } \\
(\%)\end{array}$ & $\mathrm{pH}$ & $\begin{array}{c}\text { Kireç, } \\
\mathrm{CaCO}_{3}(\%)\end{array}$ & $\begin{array}{c}\text { Organik Madde } \\
(\%)\end{array}$ & $\begin{array}{c}\text { Fosfor, } \\
\mathrm{P}_{2} \mathrm{O}_{5}\end{array}$ & $\begin{array}{c}\text { Potasyum, } \\
\mathrm{K}_{2} \mathrm{O} \mathrm{kg} / \mathrm{da}\end{array}$ \\
\hline Killi- tınlı & 0.19 & 7.08 & 10.80 & 1.33 & 4.00 & 142.78 \\
\hline
\end{tabular}

olarak uzun yıllar ortalamasının nem oranın (\%56.8) üzerinde olduğu kaydedilmiștir.

Araștırma alanında $0-20 \mathrm{~cm}$ derinlikten alınan toprak örneklerinin analizi GAP Uluslararası Tarımsal Araștırma ve Eğitim Merkezi Müdürlüğünde yapılmıștır. Araștırma alanına ait toprak analiz raporu Çizelge 3'te verilmiștir. Çizelge 3 incelendiğinde, araștırma alanının toprak yapısının killi-tınlı, hafif alkali ve az tuzlu, potasyum ve kireç içeriği bakımında zengin organik madde ve fosfor içeriği bakımdan yetersiz olduğu görülmektedir.

\section{Yöntem}

Dicle Üniversitesi kampüsü içerisinde yer alan doğal alandan toplanan bitki türlerine ait tohumlar, 2017 yılı Kasım ayında Dicle Üniversitesi Ziraat Fakültesi araștırma alanında $1.5 \times 2 \mathrm{~m}$ ebatlarındaki parsellere ekimi yapılmıștır. Ekimde sıra arası mesafe $20 \mathrm{~cm}$, sıra üzeri mesafe ise $1-2 \mathrm{~cm}$ olacak șekilde ayarlanmıș ve her parsele elle 6 sıra ekim yapılmıștır. Ekim öncesi her bir parsele dekara $8 \mathrm{~kg}$ azot ve $8 \mathrm{~kg}$ fosfor gelecek șekilde 20:20 kompoze gübre verilerek toprağa karıștırılmıștır. Üst gübre olarak 2018 yılı Șubat ayında her bir parsele $10 \mathrm{~kg} / \mathrm{da}$ saf azot gelecek șekilde üre gübresi verilmiștir. Sulama, bitkilerin sapa kalkma ve bașaklanma dönemlerinde olmak üzere 2 kez yağmurlama șeklinde yapılmıștır.

Bitkilerden örnekler çiçeklenme döneminde alınmıștır. Bitkilerden örnekler 200 gram ve üç tekerrür olacak șekilde alınmıștır. Alınan örnekler kurutma dolabında (Memmert Marka) $65^{\circ} \mathrm{C}$ sıcaklıkta 24 saat süre ile kurutulmuștur. Daha sonra bu numuneler laboratuvar tipi değirmende öğütülmüș ve $1 \mathrm{~mm}$ çaplı numune eleğinde elenmiștir. Bitkilere ait kuru madde $(K M)$, ham protein $(H P)$, asit deterjanda çözünmeyen lif (ADF), nötral deterjanda çözünmeyen lif (NDF), asit deterjanda çözünmeyen protein (ADP), kalsiyum (Ca), magnezyum $(\mathrm{Mg})$, fosfor $(\mathrm{P})$ ve potasyum $(\mathrm{K})$ ile ilgili analizler Dicle Üniversitesi Bilim ve
Teknoloji Uygulama ve Araștırma Merkezinde (DÜBTAM) NIRS (Near Infrared Spectroscopy, Foss Model 6500) cihazı kullanılarak yapılmıștır (Bașaran ve ark., 2011; Bașbağ ve ark., 2011; Çınar, 2012; Sayar, 2014; Bașbağ ve ark., 2018a,).

Araștırmada ADF ve NDF değerlerinden faydalanılarak bitki türlerinin; sindirilebilir kuru madde (SKM), kuru madde tüketimi (KMT) ve nispi yem değeri (NYD) așağıdaki eșitlikler kullanılarak hesaplanmıștır (Morrison, 2003; Bașbağ ve ark., 2011; Sayar ve ark., 2014; Bașbağ, ve ark., 2018b).

$$
\begin{aligned}
& \text { SKM }(\%)=88.9-(0.779 \times \% \text { ADF }) \\
& \text { KMT }(\%)=120 / \mathrm{NDF} \\
& \text { NYD }=(\% \text { SKM } \times \% \text { KMT }) / 1.29
\end{aligned}
$$

Ayrıca türlere ait otların nisbi yem değerleri belirlenirken Lacefield (1988)'de belirtilen sınıflandırma yöntemi esas alınmıștır.

\section{istatistiki Analizler}

Araștırmadan elde edilen verilerin varyans analizleri JMP istatistik paket programı yardımıyla yapılmıștır (SAS Institute, 2002). Ortalamalar arasındaki farklılık ise Tukey (\%5) çoklu karșılaștırma testine göre belirlenmiștir. Araștırmada Biplot analizi ve grafiği Genstat-14.0 istatistik paket programında(VSN International, 2011) Yan ve ark (2000) ile Yan ve Kang 2003'te belirtilen yöntemler dikkate alınarak belirlenmiștir. Grafik değerlendirme ve yorumları ise son yıllarda GGE biplot analizi ilgili yayın yapan araștıııcılara göre yapılmıștır (Yan ve Kang, 2003; Yan ve Tinker, 2006; illker ve ark., 2009; Kılıç ve ark., 2012; Kendal ve Sayar 2016; Kendal ve ark., 2016).

\section{Bulgular ve Tartıșma}

\section{Ham Protein ve Kuru Madde Oranları}

Buğdaygil bitki türlerinde incelenen özelliklere ait ortalamalar Çizelge 4 ve Çizelge 5 'te verilmiștir. İlgili Çizelgeler incelendiğinde, 
buğdaygil bitki türlerinin incelenen tüm özellikler bakımından 0.01 düzeyinde istatiksel olarak birbirlerinden farklı olduğu görülmektedir.

Otlardaki ham protein oranı, kaba yemin kalitesini artırdığı için mümkün olduğu kadar yüksek olması istenilir. Ayrıca otlardaki yüksek kuru madde oranı elde edilen kaba yem miktarını artırdığı için yüksek olması arzu edilmektedir. Buğdaygil türleri arasında protein oranları \%6.2 ile \%19.3 arasında değișim gösterirken, kuru madde oranları ise \%88.9 ile \%91.7 arasında değișim göstermiștir. İstatiksel olarak en yüksek ham protein oranı Aegilops cylindrica türünde, en düșük ham protein oranı ise Bromus tectorum türünde saptanmıștır. Kuru madde oranı bakımından, en yüksek kuru madde oranı Bromus tectorum türünde, en düșük kuru madde oranı ise Phalaris canariensis türünde saptanmıștır (Çizelge 4). Araștırmada ham protein oranına ilișkin saptanmıș olunan bulgular, Kılıç ve ark. (2015)'nın, Çaçan ve ark. (2015)'nın ve
Gürsoy ve Macit (2017b)'in bildirdiği bulgularla benzerlik gösterirken, Avcıoğlu ve ark. (2004) ile Canbolat (2012)'ın bildirdiği bulgulardan daha yüksek bulunmuștur. Bulgular arasındaki bu farkllığın nedeni olarak, genotiplerin, ekolojilerin ve kullanılan analiz yöntemlerinin farklı olması gösterilebilir.

\section{$A D F, N D F$ ve ADP Oranları}

Sindirilebilirlik kaba yemlerde önemli bir kalite kriteridir. Kaliteli bir kaba yem için sindirilebilirliğinin mümkün oldukça yüksek olması arzu edilir. Çünkü kaba yemlerde yüksek sindirilebilirlik oranı, hayvanların yemi rahat tüketmesini sağladığı gibi, aynı zamanda et ve süt gibi hayvansal ürünlere dönüșme oranını da arttıır. Sindirilebilirlik otlardaki selüloz, hemiselüloz ve lignin gibi hücre duvarını olușturan madde miktarlarıyla ilișkilidir. Son yıllarda otlardaki sindirilebilirlik oranları asit deterjanda çözünmeyen lif (ADF), nötral deterjanda çözünmeyen lif (NDF) üzerinden hesaplanmaktadır. ADF,

Çizelge 4. Araștırmada yer alan buğdaygil bitki türlerinin kuru otlarında saptanılan bazı kalite parametreleri (\%) ve olușan gruplar**

Table 4. Some quality parameters (\%) determined in the dry forage of the grass species in the study and forming groups

\begin{tabular}{|c|c|c|c|c|c|c|c|c|c|c|}
\hline & TÜRLER & HP & $\mathrm{KMO}$ & ADF & NDF & ADP & SKM & KMT & NYD & $\mathrm{KD}$ \\
\hline 1 & Taeniatherum caput-M. & $16.2 \mathrm{e}$ & $90.0 \mathrm{~d}$ & 27.9 & $53.2 \mathrm{~d}$ & $0.56 \mathrm{c}$ & $67.2 \mathrm{j}$ & $2.26 \mathrm{k}$ & $117.5 \mathrm{k}$ & II \\
\hline 2 & Triticum aestivum & $16.0 \mathrm{f}$ & $89.3 \mathrm{i}$ & $28.4 \mathrm{~d}$ & $52.3 \mathrm{e}$ & $0.43 \mathrm{~h}$ & 66.81 & $2.29 \mathrm{j}$ & $118.8 \mathrm{j}$ & II \\
\hline 3 & Hordeum spontaneum & $15.6 \mathrm{~h}$ & $89.4 \mathrm{~h}$ & 24.91 & $46.9 \mathrm{j}$ & $0.35 I$ & $69.5 \mathrm{~d}$ & $2.56 \mathrm{~d}$ & $137.7 \mathrm{~d}$ & I \\
\hline 4 & Secale cereale & $17.6 \mathrm{~d}$ & $90.2 \mathrm{c}$ & $26.6 \mathrm{~g}$ & $51.9 \mathrm{~g}$ & $0.53 d$ & $68.2 \mathrm{i}$ & $2.31 \mathrm{~h}$ & $122.3 \mathrm{i}$ & II \\
\hline 5 & Triticum durum & $16.2 \mathrm{e}$ & $89.0 \mathrm{j}$ & $26.3 \mathrm{~h}$ & $48.7 \mathrm{~h}$ & $0.31 n$ & $68.4 \mathrm{~h}$ & $2.46 \mathrm{~g}$ & $130.6 \mathrm{~g}$ & 1 \\
\hline 6 & Phalaris canariensis & $15.7 \mathrm{~h}$ & $88.9 \mathrm{k}$ & $25.3 k$ & $47.4 \mathrm{i}$ & $0.46 f$ & $69.2 \mathrm{e}$ & $2.53 \mathrm{f}$ & $135.9 f$ & I \\
\hline 7 & Polypogon monspeliensis & $14.2 \mathrm{i}$ & $89.7 \mathrm{f}$ & 28.2 e & 52.4 e & $0.51 \mathrm{e}$ & $66.9 \mathrm{k}$ & $2.29 \mathrm{j}$ & $118.9 j$ & II \\
\hline 8 & Bromus tectorum & 6.21 & $91.7 \mathrm{a}$ & $43.2 \mathrm{a}$ & $74.6 \mathrm{a}$ & $0.44 \mathrm{~g}$ & 55.30 & $1.61 n$ & $68.9 n$ & V \\
\hline 9 & Avena fatua & $16.2 \mathrm{e}$ & $89.6 \mathrm{~g}$ & $25.6 \mathrm{j}$ & $46.8 \mathrm{k}$ & $0.39 \mathrm{k}$ & $69.0 \mathrm{f}$ & $2.57 \mathrm{c}$ & $137.3 \mathrm{e}$ & I \\
\hline 10 & Alopecurus myosuroides & $11.9 \mathrm{k}$ & $90.0 \mathrm{~d}$ & $26.1 \mathrm{i}$ & $45.9 \mathrm{~m}$ & $0.08 \circ$ & $68.6 \mathrm{~g}$ & $2.62 \mathrm{a}$ & $139.1 \mathrm{c}$ & 1 \\
\hline 11 & Aegilops geniculata & $15.9 \mathrm{~g}$ & 89.9 e & $29.8 c$ & $57.1 \mathrm{~b}$ & $0.57 \mathrm{~b}$ & $65.7 \mathrm{~m}$ & $2.10 \mathrm{~m}$ & $107.0 \mathrm{I}$ & III \\
\hline 12 & Aegilops cylindrica & $19.3 \mathrm{a}$ & $89.8 \mathrm{f}$ & $24.8 \mathrm{~m}$ & $52.1 \mathrm{f}$ & $0.63 a$ & $69.6 \mathrm{c}$ & $2.30 \mathrm{i}$ & $124.3 \mathrm{~h}$ & III \\
\hline 13 & Poa pratensis & $13.5 \mathrm{j}$ & $90.4 \mathrm{~b}$ & $32.3 \mathrm{~b}$ & $56.6 \mathrm{c}$ & $0.42 \mathrm{i}$ & $63.8 n$ & 2.121 & $104.9 \mathrm{~m}$ & III \\
\hline 14 & Lolium perenne & $18.6 \mathrm{c}$ & $90.3 \mathrm{~b}$ & $23.0 n$ & 46.11 & $0.41 \mathrm{j}$ & $71.0 \mathrm{~b}$ & $2.60 \mathrm{~b}$ & $143.1 \mathrm{a}$ & 1 \\
\hline 15 & Festuca arundinacea & $18.8 \mathrm{~b}$ & $90.0 \mathrm{~d}$ & $22.9 \circ$ & $47.1 \mathrm{j}$ & $0.34 \mathrm{~m}$ & $71.0 \mathrm{a}$ & $2.55 \mathrm{e}$ & $140.3 b$ & I \\
\hline & Ortalama & 15.5 & 89.9 & 27.7 & 51.9 & 0.43 & 67.3 & 2.35 & 123.1 & \\
\hline
\end{tabular}

**Tüm özellikler bakımından türler arasında \%1 düzeyinde önemli farklılıklar saptanmıștır.

(HP, ham protein oranı (\%); KMO, kuru madde oranı (\%); ADF, asit deterjanda çözünmeyen lif oranı (\%); NDF, nötral deterjanda çözünmeyen lif oranı (\%); ADP, asit deterjanda çözünmeyen protein oranı (\%), SKM, sindirilebilir kuru madde oranı (\%); KMT, kuru madde tüketimi; NYD, nisbi yem değeri; KD; ot kalite derecesi) 
daha çok bir kaba yemin hayvan tarafından sindirilebilirlik durumunun belirlemesinde kullanılan bir yem değeri iken, NDF ise kaba yemlerin hayvanlar tarafından alınabilirlik durumlarının saptanmasında kullanılan bir yem değeridir. İyi bir ot kalitesi için ADF ve NDF değerlerinin mümkün olduğu kadar düșük olması istenilmektedir (Lacefield, 1988; Schroeder, 1994; Caballero ve ark., 1995; Sayar ve ark 2014; Bașbağ ve ark 2018b).

Araștırmada buğdaygil bitki türlerinde, otların ADF oranları \%22.9 ile \%43.2 arasında, NDF oranları ise \%45.9 ile \%74.6 arasında değișim göstermiștir. En yüksek ADF ve NDF oranları Bromus tectorum türünde saptanırken, en düșük ADF oranı Festuca arundinace türünde en düșük NDF oranı ise Alopecurus myosuroides türünde elde edilmiștir (Çizelge 4). Araștırma bulguları dikkate alındığında Alopecurus myosuroides türünün Bromus tectorum türüne göre çok daha yüksek oranda sindirilebilirliğe ve hayvanlar tarafından alınabilirliğe sahip olduğu söylenebilir. Araștırmada ADF ve NDF oranı ile ilgili olarak elde edilen bulgular literatür bulguları ile uyum içerisindedir (Canbolat, 2012; Çaçan ve ark., 2015; Kilıç ve ark., 2015; Gürsoy ve Macit, 2017a).

Asit deterjanda çözünmeyen protein (ADP), olumsuz çevre ve depolama șartlarından dolayı selüloz ve lignine bağlanarak sindirilebilirliğini kaybeden protein oranını ifade eden bir değerdir. Araștırmada buğdaygil bitkisi türlerinde ADP değerleri \%0.08 ile \%0.63 arasında değișim göstermiștir. En yüksek ADP oranı Aegilops cylindrica türünden kaydedilirken, en düșük ADP değeri ise Alopecurus myosuroides türünde kaydedilmiștir (Çizelge 4). Gülümser ve Acar (2012) ADP değerlerinin katran yoncası (Bituminaria bituminosa) bitkisinin yapraklarında $\% 0.02$ ile $\% 073$ arasında, saplarında ise $\% 0.02$ ile \%0.99 arasında değișim gösterdiğini bildirmișlerdir. Araștırmamızda saptanılan ADP değerleri araștıııcıların bildirdiği bu ADP değerleri aralığında olup onların bulgularıyla uyum içersindedir.

Sindirilebilir Kuru Madde Oranı (SKM) ve Kuru Madde Tüketim (KMT) Oranları ile Nisbi Yem Değerleri (NYD) ve Ot Kalite Dereceleri (KD)

Araștırmada sindirilebilir kuru madde oranları (SKM) \%55.3 ile \%71.0 arasında değișim gösterirken, kuru madde tüketim oranları (KMT) ise \%1.61 ile \%2.62 arasında değișim göstermiștir. İstatistiksel olarak en yüksek sindirilebilir kuru madde oranı Festuca arundinacea türünde saptanırken, en yüksek kuru madde tüketimi oranı Alopecurus myosuroides ve en yüksek nispi yem değeri ise Lolium perenne türlerinden elde edilmiștir. En düșük sindirilebilir kuru madde, kuru madde tüketimi ve nispi yem değeri ise Bromus tectorum türünde kaydedilmiștir (Çizelge 4). Araștırma bulgularımızla uyumlu olarak; Sayar ve ark. (2014) bazı çok yıllık buğdaygil yem bitkisi türlerinde 3 yıllık ortalamalara göre sindirilebilir kuru madde oranının \%59.2 ile 62.5 arasında, kuru madde tüketim oranlarının ise $\% 2.18$ ile \%2.49 arasında değișim gösterdiğini bildirmektedirler.

Çizelge 4'te Lacefield (1988) tarafından önerildiği șekilde nisbi yem değerleri esas alınarak türlerin ot kalite dereceleri sınıflandırılmıștır. Çizelge 4 incelendiğinde; bașta Lolium perenne ve Festuca arundinacea türleri olmak üzere Hordeum spontaneum, Triticum durum, Phalaris canariensis, Avena fatua ve Alopecurus myosuroides türlerinin otları I. derece kalite sınıfında yer almıștır. Nisbi yem değerleri 103 ile 124 arasında olan Taeniatherum caput-medesa, Triticum aestivum, Polypogon monspeliensis, Secale cereale, Polypogon monspeliensis ve Aegilops cylindrica türlerine ait otlar ise II. kalite ot sınıfında yer almıșlardır. Aegilops geniculata ve Poa pratensis türleri otları III. kalite sınıfında yer alırken, en düșük nisbi yem değerine sahip Bromus tectorum türünün otu ise $\mathrm{V}$. kalite sınıfında yer almıștır (Çizelge 4).

\section{Kalsiyum (Ca), Fosfor (P), Magnezyum (Mg)} ve Potasyum (K) içerikleri (\%)

Çalıșmada buğdaygil bitkisi otlarında saptanmıș olunan $\mathrm{Ca}, \mathrm{P}, \mathrm{Mg}$ ve $\mathrm{K}$ değerlerinin istatistiksel olarak birbirlerinden $\% 1$ düzeyinde farklı olduğu ve bu makro elementler içeriklerinin așağı belirtilen aralıklarda değișim gösterdiği saptanmıștır. Kalsiyum (Ca), \%0.25\%0.55; fosfor (P), \%0.40- \%0.49; magnezyum (Mg)- \%0.014- \%0.28 ve potasyum (K) \%2.09-\%3.85. Araștırmada kalsiyum içeriği bakımından Festuca arundinacea türü öne çıkarken, fosfor ve magnezyum içerikleri 
Çizelge 5. Araștırmada yer alan buğdaygil bitki türlerinin otlarında Kalsiyum (Ca), Magnezyum (Mg), Potasyum (K) ve Fosfor $(\mathrm{P})$ Oranları $(\%)$ ve olușan gruplar*

Table 5. Calcium (Ca), Magnesium (Mg), Potassium (K) and Phosphorus (P) contents (\%) in forage of the studied grass species and forming groups

\begin{tabular}{llccccc}
\hline & TÜRLER & $\mathrm{Ca}$ & $\mathrm{P}$ & $\mathrm{Ca}: \mathrm{P}$ & $\mathrm{Mg}$ & $\mathrm{K}$ \\
\hline 1 & Taeniatherum caput-medusa & $0.39 \mathrm{~h}$ & $0.48 \mathrm{c}$ & 0.81 & $0.26 \mathrm{~b}$ & $3.85 \mathrm{a}$ \\
2 & Triticum aestivum & $0.39 \mathrm{~h}$ & $0.45 \mathrm{f}$ & 0.87 & $0.14 \mathrm{k}$ & $2.72 \mathrm{I}$ \\
3 & Hordeum spontaneum & $0.42 \mathrm{~g}$ & $0.47 \mathrm{~d}$ & 0.89 & $0.20 \mathrm{~h}$ & $3.28 \mathrm{e}$ \\
4 & Secale cereale & $0.47 \mathrm{~d}$ & $0.47 \mathrm{~d}$ & 1.00 & $0.21 \mathrm{~g}$ & $2.98 \mathrm{i}$ \\
5 & Triticum durum & $0.45 \mathrm{f}$ & $0.45 \mathrm{f}$ & 1.00 & $0.16 \mathrm{j}$ & $2.90 \mathrm{k}$ \\
6 & Phalaris canariensis & $0.54 \mathrm{~b}$ & $0.47 \mathrm{~d}$ & 1.15 & $0.22 \mathrm{f}$ & $3.04 \mathrm{~g}$ \\
7 & Polypogon monspeliensis & $0.30 \mathrm{k}$ & $0.44 \mathrm{~g}$ & 0.68 & $0.21 \mathrm{~g}$ & $2.94 \mathrm{j}$ \\
8 & Bromus tectorum & $0.27 \mathrm{I}$ & $0.41 \mathrm{~h}$ & 0.66 & $0.17 \mathrm{i}$ & $2.20 \mathrm{~m}$ \\
9 & Avena fatua & $0.46 \mathrm{e}$ & $0.46 \mathrm{e}$ & 1.00 & $0.23 \mathrm{e}$ & $3.01 \mathrm{~h}$ \\
10 & Alopecurus myosuroides & $0.49 \mathrm{c}$ & $0.40 \mathrm{i}$ & 1.23 & $0.22 \mathrm{f}$ & $2.73 \mathrm{I}$ \\
11 & Aegilops geniculata & $0.25 \mathrm{~m}$ & $0.45 \mathrm{f}$ & 0.56 & $0.17 \mathrm{i}$ & $3.20 \mathrm{f}$ \\
12 & Aegilops cylindrica & $0.35 \mathrm{i}$ & $0.48 \mathrm{~b}$ & 0.73 & $0.24 \mathrm{~d}$ & $3.32 \mathrm{~d}$ \\
13 & Poa pratensis & $0.32 \mathrm{j}$ & $0.41 \mathrm{~h}$ & 0.78 & $0.22 \mathrm{f}$ & $2.09 \mathrm{n}$ \\
14 & Lolium perenne & $0.49 \mathrm{c}$ & $0.49 \mathrm{a}$ & 1.00 & $0.28 \mathrm{a}$ & $3.37 \mathrm{c}$ \\
15 & Festuca arundinacea & $0.55 \mathrm{a}$ & $0.46 \mathrm{e}$ & 1.20 & $0.25 \mathrm{c}$ & $3.61 \mathrm{~b}$ \\
& Ortalama & 0.41 & 0.45 & 0.91 & 0.21 & 3.01 \\
\hline
\end{tabular}

${ }^{* * G r u p l a n d ı r m a ~ y a p ı l a n ~ o ̈ z e l l i k l e r ~ b a k ı m ı n d a n ~ t u ̈ r l e r ~ a r a s ı n d a ~ \% 1 ~ d u ̈ z e y i n d e ~ o ̈ n e m l i ~ f a r k l ı l ı k l a r ~ s a p t a n m ı s ̦ t ı r . ~}$

bakımından Lolium perenne ve potasyum içeriği bakımından ise Taeniatherum çaputmedusa türü öne çıkmıștır (Çizelge 5).

Eksikliğinde hayvan kemiklerinde yumușamaya neden olan kalsiyum elementinin (Khan ve ark., 2017) kaba yemlerde en az \%0.30 olması gerektiği bildirilmektedir (Tajeda ve ark., 1985; Ayan ve ark., 2010). Araștırmada Bromus tectorum dıșındaki diğer buğdaygil yem bitkilerine ait türlerin kalsiyum açısından yeterli olduğu görülmektedir. Khan ve ark (2007)'nın çayır mera otlarındaki saptamıș oldukları kalsiyum içerikleri $(\% 0.32$ ile \%0.49), araștırma bulgularımızla tam uyum içerisindedir.

Hayvanların sakinleșmesini sağladığı için "Antistress Minerali" olarak ta bilinen magnezyum elementi, eksikliğinde hayvanlarda "Çayır Tetanisi" adı verilen felçlik hastalığına neden olabilmektedir (Ensminger ve ark., 1990; Bașbağ ve ark., 2011; Sayar, 2016). Sağlıklı bir hayvan yetiștiriciliği için yemlerde magnezyum içeriğinin \%0.12 ile \%0.20 aralığında olması gerektiği bildirilmiștir (Anonim 1980, Tajeda ve ark., 1985; Garg ve ark., 2003; Ayan ve ark., 2010). Araștırmamızda buğdaygil bitkisi otlarının çoğu bu referans aralığında yeralırken, bir kısım türlerin magnezyum içerikleri referans aralığının üzerinde olduğu görülmüștür (Çizelge 5). Araștırma bulgularımızla uyumlu olarak Khan ve ark. (2007) çayır mera otlarının kuru maddesinde magnezyum içeriğinin $\% 0.23$ ile \%0.026 arasında değiștiğini bildirmektedirler.

Hayvan beslemede kullanılacak yemlerde Ca:P oranı oldukça önemlidir. Ca:P oranının hayvan yemlerinde 1:1 ile 2:1 arasında olması gerektiği bir çok araștırmacı tarafından belirtilmiștir (Ayan ve ark., 2010; Albu ve ark., 2012; Grzegorczyk ve ark., 2017; Sayar, 2016). Ca:P dengesi bozulması durumunda hayvanlarda zehirlenmeler ortaya çıktığı vurgulanmıștır (Ayan ve ark., 2010). Araștırmada ele alınan buğdaygil yem bitkilerinin Ca:P oranına bakıldığında Secale cereale, Triticum durum, Phalaris canariensis, Avena fatua, Alopecurus myosuroides, Lolium perenne ve Festuca arundinacea türlerinde ideal oranın yakalandığı, diğer türlerin ise ideal 
Ca:P oranının altında kaldığı görülmektedir. En düșük Ca:P oranı Bromus tectorum ve Aegilops geniculata türlerinden elde edilmiștir (Çizelge 5).

\section{Özelliklerarası ilișkilerinin Biplot Analiz Yöntemi Değerlendirilmesi}

Șekil 1'de özellikler ve türler arasındaki interaksiyonu gösteren grafikte \% PC1 (\%62.24) (the first Principal Component - 1. Ana Bileșen) \% PC2 (the second Principal Component- 2. Ana Bileșen) (\%17.81) değerleri toplamı \%82.05 olarak hesaplandığı görülmektedir. $\mathrm{Bu}$ iki değer toplamının araștırmamızda olduğu gibi yüksek olması biplot grafiklerinde daha güvenli yorum yapmayı sağlamaktadır (Fırıncıoğlu ve ark., 2012; Sayar ve Han, 2015).

Ayrıca Șekil 1'de buğdaygil bitki türlerinde incelenen özelliklerin birbirleriyle ve türlerle olan ilișkisi görsel olarak belirtilmiștir. Șekil 1 incelendiğinde, araștırmada incelenen özelliklerin istatiksel olarak beș değișik grup olușturduğu görülmektedir. İncelenen özelliklerden ADF, NDF ve Kuru madde oranı (KMO) özelliklerinin grafik üzerinde birbirlerine yakın konumlanarak aynı grupta yer aldıkları görülmektedir. Bu grubu olușturan üç özellik

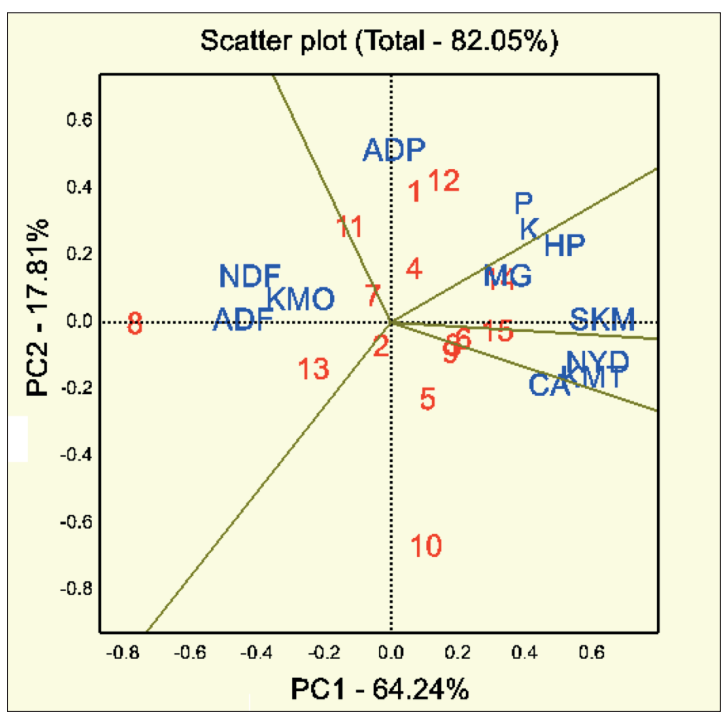

Șekil 1. Buğdaygil bitki türlerinde incelenen özelliklerin birbirleriyle olan ilișkisi ile tür-özellik interaksiyonunu gösteren biplot grafiği

Figure 1. Biplot graph showing the relationships among the investigated traits and interactions between the traits and grass species bakımından özellikle öne çıkan türler Bromus tectorum (8) ve Poa pratensis (13) türleri olmuștur. Bu iki türde ADF ve NDF değerlerinin yüksek olmasına bağlı olarak sindirilebilir kuru madde oranı, kuru madde tüketim oranı ve nisbi yem değerleri düșük bulunmuș, dolayısıyla düșük kalitede ot ürettikleri saptanmıștır (Çizelge 4, Șekil 1). Öte yandan, sindirilemeyen protein (ADP), fosfor $(P)$ ve potasyum içerikleri arasında olumlu ilișki bulunmuș ve bu üç özellik bakımından özellikle Taeniatherum caputmedusa (1), Secale cereale (4) ve Aegilops cylindrica (12) nolu türler öne çıkmıștır. Diğer taraftan ham protein oranı (HP), magnezyum (MG) ve sindirilebilir kuru madde oranı (SKM) özellikleri aynı grupta yer almıș olup, bu grupta yer alan özellikler bakımından Lolium perenne (14) türünün öne çıkması dikkat çekici bulunmuștur. Ot kalitesinde önemli parametrelerden olan kuru madde tüketim oranı (KMT) ve nisbi yem değerleri (NYD) özelliklerinden olușan grupta ise Festuca arundinacea ve Phalaris canariensis türleri yer almıștır. Son olarak otların kalsiyum (Ca) oranı özelliği tek bașına bir grup olușturmuș, bu grupta Alopecurus myosuroides ve Triticum durum (10) türleri ön plana çıkmıștır.

\section{Sonuç}

Araștırmada 13 değișik buğdaygil cinsine ait 15 buğdaygil yem bitkisi türünde incelenen özellikler açısından istatistiki olarak 0.01 düzeyinde çok önemli farklılıklar saptanmıștır. Bromus tectorum türü dıșındaki diğer türlerin uygun zamanda hasat edilmelerine bağlı olarak yeterli düzeyde ham protein oranı içerdikleri, hayvanlar tarafından tüketilme ve sindirilme oranları ile nisbi yem değerlerinin iyi olduğu belirlenmiștir. Makro elementler açısından bakıldığında ise Bromus tectorum dıșındaki türlerin yeterli düzeyde $\mathrm{Ca}$ ve $\mathrm{P}$ içerdikleri ve tüm türlerde $\mathrm{Ca}: \mathrm{P}$ oranı açısından zehirlenmelere yol açabilecek yüksek bir oranın olmadığı görülmüștür. K oranı açısından tüm türlerin, $\mathrm{Mg}$ oranı açısından ise bir çok türün yeterli düzeyde olduğu görülmüștür. Araștırmada Bromus tectorum dıșındaki diğer 14 buğdaygil yem bitkisi türünün hayvan beslenmesinde kullanılabileceği sonucuna varılmıștır. 


\section{Kaynaklar}

Açıkgöz, E., (2001). Yem Bitkileri. Uludağ Üniversitesi Güçlendirme Vakfı Yayın No: 182., s.135.

Albu, A., Pop, I.M., Radu-Rusu, C., (2012). Calcium $(\mathrm{Ca})$ and phosphorus $(\mathrm{P})$ concentration in dairy cow feeds. Lucrări Științifice- Seria Zootehnie. 57(17): 70-74.

Anonim. (1980). The Nutrients Requirements of Ruminant Livestock. 4th ed. 73-310. CAB International, Wallingford.

Anonim, (2018). Diyarbakır ili meteoroloji verileri. Diyarbakır Meteoroloji Bölge Müdürlüğü.

Avcıoğlu, R., Demiroğlu, G. ve Geren, H. (2004). Bazı yeni yem bitkisi cins tür ve çeșitlerinin Ege Bölgesi koșullarında verim ve yem kalite özellikleri üzerinde araștırmalar. Türkiye Bilimsel ve Teknolojik Araștırma Kurumu, Proje No: TOGTAG-2847.

Avcıoğlu, R., Hatipoğlu, R. ve Karadağ, Y. (2009). Yem Bitkileri Cilt III. Tarım ve Köyișleri Bakanlığı Tarımsal Üretim ve Geliștirme Genel Müdürlüğü, s.546.

Ayan, I., Mut, H., Önal-Ascl, O., Basaran U. and Acar, Z. (2010). Effects of manure application on the chemical composition of rangeland hay. Journal of Animal and Veterinary Advances. 9(13): 1852-1857.

Bașaran, U., Mut, H., Önal Așçı, Ö., Acar, Z. and Ayan, i. (2011). Variability in forage quality of Turkish grass pea (Lathyrus sativus L.) landraces. Turkish Journal Field Crops. 16(1): 9-14.

Bașbağ, M., Çaçan, E., Aydın, A. ve Sayar M. S., (2011). Güneydoğu Anadolu Bölgesi doğal alanlarından toplanan bazı fiğ türlerinin ot yönünden kalite özelliklerinin belirlenmesi. Uluslararası Katıımlı I. Ali Numan Kıraç Tarım Kongresi ve Fuarı, Bildiriler Kitabı Cilt: 1, 27-30 Nisan, s: 143-152, Eskișehir.

Bașbağ, M., Çacan, E., Sayar M. S. and Karan, H. (2018a). Identification of certain agricultural traits and inter-trait relationships in the Helianthemum ledifolium (L.) Miller var. lasiocarpum (Willk.) Bornm. Pakistan Journal of Botany. 50(4): 13691373.

Bașbağ, M., Çaçan, E., Sayar M. S., Karan, H. ve Tonçer, Ö. (2018b). Bazı tıbbi ve aromatik bitkilerin yem kalitesi açısından değerlendirilmesi. Türkiye Tarımsal Araștırmalar Dergisi. 5(3): 246-252.

Caballero, A. R., Goicoechea-Oicoechea, E. L., Hernaiz-Ernaiz, P. J. (1995). Forage yields and quality of common vetch and oat sown at varying seeding ratios and seeding rates of vetch. Field Crops Research. 41:135-140.

Canbolat, Ö. (2002). Bazı Buğdaygil kaba yemlerin in vitro gaz üretimi, sindirilebilir organic madde, nispi yem değeri ve metabolic enerji içeriklerinin karșılașırılması. Kafkas Üniversitesi Veteriner Fakültesi Dergisi. 18(4): 571-577.

Çaçan, E., Aydın, A. ve Bașbağ, M. (2015). Bingöl Üniversitesi Yerleșkesinde Yer Alan Bazı Buğdaygil Yem Bitkilerine Ait Kalite Özelliklerinin
Belirlenmesi. Türk Tarım ve Doğa Bilimleri Dergisi. 2(2): 214-219.

Çınar, S., (2012). Çukurova taban koșullarında bazı çok yıllık sıcak mevsim buğdaygil yem bitkilerinin yonca (Medicago sativa L.) ile uygun karıșımlarının belirlenmesi. Doktora Tezi, Çukurova Üniversitesi Fen Bilimleri Enstitüsü, Adana.

Ensminger, M. E., Oldfield, J. E. and Heinemann, W. W. (1990). Feeds \& Nutrition, second ed., The Ensminger Publishing Company, California, U.S.A., p: 890.

Fırıncıoğlu, H. K., Ünal, S., Pank, Z. and Beniwal S. P. S. (2012). Growth and development of narbon vetch (Vicia narbonensis L.) genotypes in the semi-arid central Turkey. Spanish Journal of Agricultural Research. 10(2): 430-442.

Garg, M. R., Bhanderi, B. M. and Sherasia, P. L., (2003). Macro-mineral status of feeds and fodders in Kutch district of Gujarat. Animal Nutrition and Feed Technology, 3(2):179-188.

Grzegorczyk, S., Alberski, J., Olszewska, M., Grabowski, K. and Bałuch-Małecka, A., (2017). Content of calcium and phosphorus and the Ca:P ratio is selected species of leguminous and herbaceous plants, Journal of Elementology. 22(2): 663-669.

Gülümser, E. and Acar, Z. (2012). Morphological and chemical characters of Bituminaria bituminosa (L) c.h. (Stirtion) grown naturally in the Middle Black Sea Region. Turkish Journal of Field Crops, 17(2): 101-104.

Gürsoy, E. ve Macit, M. (2017a). Erzurum ili çayır ve meralarında doğal olarak yetișen bazı buğdaygil yem bitkilerinin nispi yem değerleri bakımından karșılaștırılması. Yüzüncü Yı Üniversitesi Tarım Bilimleri Dergisi. 27(3): 309-317.

Gürsoy, E. ve Macit, M. (2017b). Erzurum ili çayır meralarında doğal olarak yetișen bazı baklagil ve buğdaygil yem bitkilerinin mineral madde kompozisyonlarının belirlenmesi. Alınteri. 32(1): 1-9.

İlker, E., Aykut Tonk, F., Çaylak, Ö., Tosun,M. ve Özmen, I. (2009). Assessment of genotype $x$ environment interactions for grain yield in maize hybrids using AMMI and GGE biplot analyses. Turkish Journal of Field Crops, 14(2): 123 - 135.

Kendal, E. and Sayar, M. S. (2016). The stability of some spring triticale genotypes using biplot analysis. Journal of Animal and Plant Sciences. 26(3): 754-765.

Kendal, E., Sayar, M. S., Tekdal, S., Aktaș H. and Karaman, M. (2016). Assessment of the impact of ecological factors on yield and quality parameters in triticale using GGE biplot and AMMI analysis. Pakistan Journal of Botany, 48(5): 1903-1913.

Kevseroğlu, K. (2000). Tarla Tarımı-1. Ondokuz Mayıs Üniversitesi Ziraat Fakültesi Ders Kitabı No:36, s.20.

Kılıç, H., Tekdal, S., Kendal, E. ve Aktaș, H. (2012). Augmented deneme desenine dayalı ileri 
kademe makarnalık buğday (Triticum turgidum ssp durum) hatlarının biplot analiz yöntemi ile değerlendirilmesi. Kahramanmaraș Sütçü İmam Doğa Bilimleri Dergisi, 15(4): 18-25.

Kılıç, Ü., Yurtseven, S., Boğa, M. ve Aydemir, S. (2015). Farklı toprak tuzluluk düzeylerinin bazı buğdaygil yem bitkilerinin in vitro gaz üretimi ve yem değerleri üzerine etkisi. Toprak Bilimi ve Bitki Besleme Dergisi. 3(1): 9-15.

Khan, Z. I., Ashraf, M., Hussain, A., (2007). Evaluation of macro mineral contents of forages: influence of pasture and seasonal variation. Asian-Australasian Journal of Animal Sciences. 20(6): 908-913.

Lacefield, G. D., (1988). Alfalfa Hay Quality Makes the Difference. University of Kentucky Department of Agronomy AGR-137, Lexington, KY.

Morrison, J. A. (2003). Illinois Agronomy Handbook. Hay and Pasture, Chapter 6. Rockford Extension Center. (http://extension.cropsciences.illinois. edu/handbook/ pdfs/chapter06.pdf), (Erișim tarihi: 11.10.2018).

Sağlamtimur, T., Gülcan, H., Tükel, T., Tansı, V., Anlarsal, A. E. ve Hatipoğlu, R.,(1986). Çukurova koșullarında yembitkileri adaptasyon denemeleri 1. Buğdaygil Yembitkileri”, Ç.Ü. Ziraat Fakültesi Dergisi, 1: 26-36.

SAS Institute, (2002). JMP Statistics. Cary, NC, USA: SAS Institute, Inc. pp.70.

Sayar M. S., Anlarsal A. E. ve Bașbağ, M. (2010). Güneydoğu Anadolu Bölgesinde yem bitkileri tarımının mevcut durumu sorunları çözüm önerileri, Harran Üniversitesi Ziraat Fakültesi Dergisi,14(2): 59-67.

Sayar, M. S., Kendal, E. (2014). Tek yıllık baklagil yem bitkilerinin tahıllarla karıșık ekimi. Mardin Gıda Tarım ve Hayvancılık Dergisi, Yıl: 4, Sayı: 11, Sayfa: 52-54.

Sayar, M. S., (2014). Path coefficient and correlation analysis between forage yield and its affecting components in common vetch (Vicia sativa L.). Legume Research. 37(5): 445-452.
Sayar, M. S., Han, Y. (2015). Mürdümük (Lathyrus sativus L.) Hatlarının tohum verimi ve verim komponentlerinin belirlenmesi ve GGE biplot analiz yöntemiyle değerlendirilmesi. Tarım Bilimleri Dergisi- Journal of Agricultural Sciences. 21(1): 78-92.

Sayar, M. S., Han, Y., Yolcu, H. and Yücel, H., (2014). Yield and quality traits of some perennial forages as both sole crops and intercropping mixtures under irrigated conditions. Turkish Journal of Field Crops. 19(1): 59-65.

Sayar, M. S., (2016). Dry matter yield and forage quality of promising bitter vetch (Vicia ervilia (L.) Willd.) lines. VII International Scientific Agriculture Symposium, Book of Proceedings Jahorina, October 06-09, 2016 Sarajevo, Bosnia and Herzegovina p: 283-291.

Schroeder, J. W. (1994). Interpreting Forage Analysis. Extension Dairy Specialist (NDSU), AS-1080, North Dakota State University.

Tajeda, R., Mcdowell, L. R., Martin, F.G. and Conrad, J. H., (1985). Mineral element analyses of various tropical forages in Guatemala and their relationship to soil concentrations. Nutrition Reports International. 32: 313-324.

VSN International, 2011. GenStat for Windows 14th Edition. VSN International, Hemel Hempstead, UK. Web page: GenStat.co.uk.

Yan, W., Hunt, L.A., Sheng $Q$ and Szlavnics, Z. (2000). Cultivar evaluation and megaenvironment investigation based on the GGE biplot. Crop Science. 40: 597-605.

Yan, W., Kang M. S. (2003). GGE Biplot Analysis: A Graphical Tool for Breeders, Geneticists, and Agronomists. CRC Press, Boca Raton, FL, pp.288.

Yan, W. and Tinker N. A. (2006). Biplot analysis of multi-environment trial data: Principles and applications. Canadian Journal of Plant Science. 86: 623-645. 